\title{
Ethnologies
}

\section{Irish-Newfoundland Step Dancing and Cultural Identity in Newfoundland}

\section{Kristin Harris Walsh}

Volume 30, numéro 1, 2008

Danse au Canada

Dance in Canada

URI : https://id.erudit.org/iderudit/018838ar

DOI : https://doi.org/10.7202/018838ar

Aller au sommaire du numéro

Éditeur(s)

Association Canadienne d'Ethnologie et de Folklore

ISSN

1481-5974 (imprimé)

1708-0401 (numérique)

Découvrir la revue

Citer cet article

Walsh, K. H. (2008). Irish-Newfoundland Step Dancing and Cultural Identity in Newfoundland. Ethnologies, 30(1), 125-140. https://doi.org/10.7202/018838ar
Résumé de l'article

Le step dancing à Terre-Neuve et au Labrador a subi un important changement contextuel afin de conserver sa pertinence en tant qu'objet culturel et genre performatif ; et le contexte dans lequel il se développe, ainsi que sa fonction, continuent d'évoluer à l'heure actuelle tout en collant à l'identité collective de Terre-Neuve. Au travers de l'étude des danseurs de St Pat, un groupe de jeunes " step danseurs » de St John's, cet article aborde des questions philosophiques plus larges concernant l'authenticité, le patrimoine et le renouveau dans la danse vernaculaire. L'exemple des danseurs de St Pat associe les notions de mise en valeur et de conservation du patrimoine à la marchandisation de la culture au travers du sentiment identitaire irlandais qui prévaut à Terre-Neuve. 


\section{Irish-Newfoundland Step Dancing ANd Cultural IDENTITY IN NEWFOUNDLAND}

Kristin Harris Walsh

Memorial University of Newfoundland

Irish step dancing is a worldwide phenomenon today. ${ }^{1}$ With the advent of "Riverdance" in the 1990s, step dancing sprang up all over the world, bringing what was a traditional dance form crashing into the twenty-first century, complete with flashy costumes and electrified Celtic music. ${ }^{2}$ However, not only is "Riverdance" a stylized form of traditional Irish step dancing, it is very different from other forms of vernacular step dancing. As much as the influence of "Riverdance" resonates in Newfoundland and Labrador in 2008, it is by no means its earliest or longest-standing form of step dance. In fact, Newfoundland and Labrador has seen several forms of step dancing evolve over the years, enjoying parallel development with the recontextualization of dance from participatory to performance activity, and the cultural revival that occurred in the 1970s.

Today, three main forms of step dancing exist in the province: vernacular Newfoundland step dance, Irish-Newfoundland step dance, and traditional Irish step dance. This article examines IrishNewfoundland step dancing through its chief proponents, the St. Pat's Dancers, a children's step dance group based in Newfoundland's capital city, St. John's. This study is based on fieldwork conducted throughout

1. This article began as a chapter of my doctoral dissertation. I'd like to thank my informants, Jeff and Yvonne Steiner, as well as the St. Pat's Dancers, for their generosity during my fieldwork. The ideas in this article have benefited greatly from input from Diane Tye, Andriy Nahachewsky, Philip Hiscock and Kieran Walsh. I would also like to gratefully acknowledge funding from ISER and the Smallwood Foundation during my dissertation research and writing.

2. See Casey 2002 and Tomell-Presto 2003 for discussion of the theatricalized nature of "Riverdance." 
2004 and 2005 with the St. Pat's Dancers through both observation and interviews. In this article, I analyze the dance style within the collective identity of the "Irishness" of Newfoundland culture, its historical links and its connections - actual and perceived - today. Just as Frank Hall asserts that his use of the term "Irish step dancing" means that he takes "the nationalist claim seriously, i.e. that competitive step dancing represents Ireland itself" (1997: 137), so do I use the term "Irish-Newfoundland set dance" to reflect the significance of Irish influence on the Newfoundland nationalist identity. This Irish characteristic pervades Newfoundland culture, especially the arts, and I position Irish-Newfoundland step dance in the midst of that IrishNewfoundland identity to suggest some reasons for the enduring popularity of related dance forms.

Irishness in Newfoundland culture is, in part, the legacy of the diaspora that exists today as a result of migration and settlement of European groups such as the English and the Irish to Newfoundland, as well as other parts of Canada and the northeastern United States. It relies on the notion that identity goes beyond one's actual national affiliation, that it is based upon an internalized identity that is manifest in both tangible and intangible cultural product and expression. Similar to how McKay (1992) has identified tartanism with Nova Scotian culture (including Scottish performative culture such as the Highland Fling), so has Irishness pervaded the Newfoundland sensibility. Because of this, Newfoundland's identity is manifest in many Irish-based folkloric and cultural products. Some are long-standing customs while others are more readily identifiable as invented traditions. ${ }^{3}$ As John Mannion indicates, Irishness is manifest in everything from the migration patterns of early Newfoundland to the proliferation of Irish music on the radio beginning in the 1950s to the "rediscovery" of Irish roots through the flourishing of Memorial University of Newfoundland, in particular, programs such as Folklore and Newfoundland Studies (2007). The ideological links between Ireland and Newfoundland are rooted in a myriad of commonalities, some tangible, others intangible, all highly symbolic. From landscape to ethnic stereotype, Ireland and Newfoundland share perceived and real similarities that have enabled and perhaps encouraged Newfoundland culture to model itself after that of Ireland. Nowhere is this more prevalent than in the arts.

3. The Telegram newspaper published an article written by Monica Baird about the perceived Irishness of Newfoundland culture - despite the lack of demographic support for this sentiment — as recently as October 15, 2006. 
In his article "The Heritage Arts Imperative", Barre Toelken argues that the most intense cultural products are found on the periphery. $\mathrm{He}$ states:

In the old homeland, culture and language continue to be modified and naturally change, but out on the margins, among people trying to maintain a cultural identity in new places, arts often become more noticeably conservative and yet, of course, also dynamic and emergent due to their performance in a fresh setting (2003: 199).

As Toelken identifies in this article, all forms of the arts - folk, heritage and fine, as he identifies them - exist along a spectrum of identity with their culture and community (2003: 196). The arts therefore influence the development of identity in a given culture. This concept is applied to the Irish in Boston in Susan Gedutis's See You at the Hall (2004). Here, she uses the Irish immigrants to Boston as a means of examining identity in the American diaspora, as expressed through the creative arts. Gedutis's study illustrates Toelken's idea that the expressive arts may become more significant on the periphery, becoming a signifier of not just the land that was left, but the people, customs and way of life that some may try to preserve in their new homes. And as the next generation is born and the family moves symbolically further and further away from its homeland, some may cling to these vernacular expressions as a way of safeguarding a vanishing part of their family's identity. Similar to Gedutis's analysis of Boston, so has Irishness flourished in Newfoundland through the arts.

In recent years, "Riverdance" has arguably been the most significant purveyor of Irishness on a global scale. Since the Riverdance phenomenon pervaded the world stage, there has been renewed interest in traditional step dancing in Newfoundland. In a newspaper interview in 1997, Francie Gow, then fiddle player for the St. Pat's Dancers, stated:

Maybe Riverdance is doing for step dancing what many groups are doing for traditional culture. It's moving the traditional into popular culture with a nice smooth transition, without losing any of the traditional merits.... Younger generations, people like myself and my friends are really enjoying it without any embarrassment (VaughnJackson).

According to Gow, because "Riverdance" brought step dancing into the popular realm, it has not only brought it into the forefront of the global consciousness, it has made it appealing to watch and practice and perform. Because of this, Gow states that there is a renewed interest 
in the more traditional forms of step dance, thereby merging vernacular and the popular and allowing both to exist comfortably within the same cultural space. ${ }^{4}$ As Peter Narváez and Martin Laba assert in the introduction to their book Media Sense, there needs not necessarily be a dichotomy between folklore and popular culture. Rather, a continuum exists that allows for both dynamism and conservatism to exert influence over the most traditional and the most mass-mediated cultural products (1986: 1-2). Thus the positive effects of "Riverdance" on awareness of step dancing in Newfoundland culture reflects the continuum asserted by Narváez and Laba in their study.

Step dance in Newfoundland, similar to other art forms, exists along this folklore-popular culture continuum largely because of the shifts in context it has undergone over the years. In his reflexive piece "On Folk Festivals and Kitchens: Questions of Authenticity in the Folksong Revival”, I. Sheldon Posen explores the significance of context in Newfoundland music. He does this by discussing his struggle to reconcile the authenticity of folk festivals and other performance venues as valid outlets for folk music performance versus the living tradition of Newfoundland folksongs in outport kitchens across the island. Eventually, Posen concluded that contexts and "how [contexts] shape the meaning of the activities within them" are key (Posen in Rosenberg 1993: 136). Posen's concept of recontextualization is relevant to the contextual shifts in dance in Newfoundland. While vernacular dance has declined in Newfoundland as a social event, as a part of the cultural revival in the late twentieth century, great pains have been taken to preserve, revive, and continue the dance form. Its recontextualization is the reason it is still danced and seen. While the dances are not passed on from generation to generation through oral and kinesthetic transmission, the more formalized teaching and performances have allowed the dances to exist in a contemporary form. And while improvised step dancing may not be performed regularly in kitchens and community halls, a variant is found in the clubs where Irish-inspired and Irish-Newfoundland music is played. Just as present-day audiences have embraced updated jigs and reels, so have they taken vernacular step dancing and incorporated it in spontaneous dancing in the club scene. Although it has changed somewhat, the spirit of traditional Newfoundland step dance continues.

4. Formal interviews and informal conversations with step dance teachers in Newfoundland and Ireland in 2006 and 2007 attribute increased enrollment in their step dance classes, in large part, as a legacy of "Riverdance." 
The Irish-Newfoundland step dance style was brought to Newfoundland and Labrador by the Christian Brothers and has continued over the years by the St. Pat's Dancers. Although the dance style is generally known as Irish-Newfoundland step dance, Jeff Steiner, head of the St. Pat's Dancers, refers to it as Irish-Newfoundland tap. By doing so he distinguishes the hard shoe work of the St. Pat's Dancers from soft-shoe Irish dancing (Vaughn-Jackson 1997). I will use the common terminology, Irish-Newfoundland step dancing, to describe the work of the St. Pat's Dancers. However, it is important to note that all the work they do is with hard shoes. Before moving into the dance style itself, a brief history of the St. Pat's Dancers and the IrishNewfoundland step dance style will be helpful. ${ }^{5}$

The St. Pat's Dancers have enjoyed a prominent place in the St. John's community for more than sixty years, and are indeed one of the most recognized dance groups, traditional or otherwise, in the province. They are also considered to be the oldest dance group in Atlantic Canada. ${ }^{6}$ Harkening back to the 1930s, the St. Pat's Dancers has undergone several small but significant changes since its original formation. It is currently billed as "a non-profit, school-based organization made up of school aged children who perform a variety of Irish/Newfoundland tap dances to traditional Newfoundland music". ${ }^{7}$ The St. Pat's Dancers' purpose and functions today are fairly similar to those found throughout the group's history.

The St. Pat's Dancers and the Irish-Newfoundland step dance style find their roots in Ireland. This style of step dancing was brought to Newfoundland along with the Christian Brothers, who initially arrived in St. John's in 1876, to teach in the Catholic school system. However, it took a number of years for step dancing to become a part of the Brothers' curriculum in St. John's. In the 1930s, at St. Patrick's school, Brother Samuel Murphy founded the St. Pat's Dancers. The small group - consisting of five boys from the school - was taught a number of Irish step dances, and they began to perform these dances throughout

5. There seems to be an accepted oral history of the dance group, published through materials produced by the St. Pat's Dancers and newspaper articles on the group. In my interviews with Yvonne and Jeff Steiner, the same details were given to me on several occasions. While references to written sources are noted here, all points were corroborated during my interviews (Y. Steiner 2004; Y. and J. Steiner 2005).

6. The St. Pat's Dancers. Summary Information. No date.

7. St. Pat's Dancers General Information. No date. 
St. John's at a variety of events, a precedent that carries through to the group today (Innes 1979). Brother Max Murray brought dances from New York in the 1940s, broadening the repertoire of the group and furthering their dance knowledge ("St Pat's Dancers"). Having studied with Fred Astaire and Ginger Rogers, Brother Murray brought a flair for performance along with dances learned in the American-Irish communities in New York ("The St. Pat's Dancers" 1994). Thus crosscultural influences have affected the Irish-Newfoundland dance style since its inception in Newfoundland.

Over the years, the group has flourished under the tutelage of a number of Christian Brothers, the last being Brother Pike. At the end of his time with the group, in the mid-1990s, it looked as though the St. Pat's Dancers was going to close down, and so spousal team Yvonne and Jeff Steiner, the current leaders, took over. They are now in their eighteenth year and have a healthy complement of children under their wing. In 2004, when I conducted my fieldwork, the group enjoyed membership of approximately fifty children, boys and girls, aged five to sixteen. The senior group consisted of approximately thirteen or fourteen children with the remainder acting as apprentices of sorts as they learned the dances and prepared for future performances (Y. Steiner 2004). According to my interviews with the Steiners, the dances are fairly static in that they have not undergone significant changes over the years; it is the repertoire itself that has grown with the group.

Step dancing concentrates its attention on the feet; they are the main focus of any step dance style. The inherent beauty of group step dancing comes from a group of dancers executing the same steps in tandem, flawlessly. While step dancing looks extremely complicated, the actual number of distinct steps is small. Its intrinsic complexity comes from the speed, accuracy, and difficult combinations in which these steps are arranged. Well-performed step dancing also produces strong, rhythmic noises with the shoes; the single sound produced by multiple dancers stepping together adds to the aesthetic quality of the dances and is unique in some ways to this dance style. The focus on the feet is paramount, and step dancing of any style showcases the speed, strength and flexibility of the foot. Step dance technique reflects the significance of the foot as the primary articulation of dance steps. Shoes enhance the aesthetics of the style and enable dancers to highlight the foot while dancing. The use of a special dance shoe is something that differentiates the more performative style of Irish-Newfoundland step 
dancing from traditional Newfoundland step dancing, which would be danced in street shoes. The St. Pat's Dancers wear standard tap shoes while dancing. Their shoes resemble a lace-up street shoe, with a few exceptions. The shoes are made of soft, supple and thin leather; this makes them durable while remaining flexible for the foot. Some of the shoes for younger children are made of patent leather, which is somewhat heavier, providing extra support for young feet. All tap shoes have metal "taps", or plates, screwed on to the bottom of the toe and heel. Irish step dance shoes are similar to tap shoes, except they have a higher heel and a higher arch. Instead of the metal taps, the toes and heels are made of fiberglass, which gives a richer tap sound, while enabling more difficult steps such as dancing on the tips of the toes, which are not possible in tap shoes. The aesthetic of the modern-day tap or Irish step dance shoe is derived from earlier practices which required dancers to modify regular street shoes. Dancers would attach leather tips on the toes of their shoes and fasten a tack or a nail to the leather strip, thereby enabling the dancer to create a functional, if rudimentary tap on the toes (Foley 1988: 12). While many Irish dance schools across North America require beginner students to wear soft shoes before they can "graduate" to hard shoes (Long 1999), the St. Pat's Dancers only use tap shoes, and the Irish-Newfoundland step dance style consists solely of steps that can be performed in tap shoes. This, of course, produces the distinctive sounds that are the rhythmic and technical basis of the dance form.

Over the years, step dance in Newfoundland and Labrador has undergone significant changes in context, and corresponding functional differences. Stepping in this province evolved from a social event into a performance genre primarily through the influence of Irish immigrants to Newfoundland in the 1930s, and again in the 1990s. While the dancespecific influences arrived in these two waves, it is because of the established prevalence of Irish culture in Newfoundland and Labrador society that these dance forms flourished. Although a majority of the population of Newfoundland and Labrador is of English descent, it is arguable that Irish popular entertainments have had more staying power (and certainly more consumer appeal, especially in the tourist industry) in Newfoundland and Labrador culture. Because step dancing is intrinsically linked to its Irish roots, Irish identity is found here. Today, performances dominate as the primary mode of step dance presentation, in both vernacular and contemporary forms. Of course, contextual shifts in performance are evident in any vernacular genre in the performing 
arts. What sets the Newfoundland example of vernacular dance apart, then, is that the shift arrived rather markedly through the changing context from the kitchen to the stage.

Perhaps the most commonly accepted reason for the shift in context of much of Newfoundland and Labrador's folklife traditions is modernization. As communities' isolation became less marked, as electricity and its resultant inventions (such as television) became household staples, it is generally acknowledged that so-called traditional activities, such as storytelling and dancing, began to decline in practice. The resurgence of vernacular dance, along with music, was actively pursued by proponents of what Overton (1996) has documented as Newfoundland's cultural revival in the 1970s and 1980s. Most recently, tourism can be seen as a significant push towards the promotion of vernacular performing genres. Irish identity has been popularized in Newfoundland and Labrador culture through the years, influenced not only by immigration and settlement patterns of early Newfoundland, but by traditional and popular arts as well. ${ }^{8}$ Music, in particular, is key to Irish identity in this regard. From the McNulty Family, to the Clancy Brothers and Tommy Makem, to Ryan's Fancy and the Sons of Erin, popular Irish music has been at the forefront of Newfoundlanders' consciousness for many years. ${ }^{9}$ Terry McDonald postulates in his study of Newfoundland folk song that the Irishness of Newfoundland folk song has crowded out earlier English influence, particularly from the West Country of England (1999: 180). He concludes that, from viewing folksong as a glimpse into a culture's past, "I find both disappointing and disturbing the promotion of a body of music that purports to be an 'authentic' manifestation of the Newfoundland's past but in fact is a modern creation” (1999: 190). Traditional and contemporary music created by Newfoundlanders has also been significantly paralleled to the Irish example, enabling an "Irishness" to pervade Newfoundland cultural identity and pave the way for other Irish art forms such as dance to become more prevalent and popular throughout the province.

In particular, what Overton (1996) called the Newfoundland "cultural revolution" of the 1970 s and 1980s, reveals a logical

8. See Johnston 1996 for an outline of the influence of Irish music and dance on Irish-American communities.

9. See Pat Byrne's 1991 article, "Stage Irish in Britain's Oldest Colony: Introductory Remarks Towards an Analysis of the Influence of the McNulty Family on Newfoundland Music", for a discussion of popular Irish music in Newfoundland. 
commingling of the arts and the Irish identity. Overton identifies this cultural revolution at the time when Memorial University of Newfoundland's Extension Services and Folklore Department were founded, as was the Institute for Social and Economic Research. Overton argues that Newfoundland's cultural revolution was based on, "the assumption that Newfoundland has a distinctive culture, way of life, soul, identity" and that the cultural lens of the romanticized view of Newfoundland life and culture informed the worldview of Newfoundlanders. The arts, then, came to the forefront of Newfoundland consciousness. As John G. Robb argues in his article "A Geography of Celtic Appropriations", in the book Celtic Geographies: Old Culture, New Times, the "Celtic" can be read through its intrinsic links to "language, folklore, history, music, dance, art and design" (Harvey et al. 2002: 233). While Robb is discussing the Celtic phenomenon throughout Europe, through his concept of what he calls Europe's new "Celtomania", he acknowledges the pervasiveness of the Celtic culture, particularly the arts, beyond Atlantic Europe (Harvey et al. 2002: 229). In her article "Riverdance: The Importance of Being Irish American", Natasha Casey identifies the significance of the "Celtic" in American culture, through her study of "Riverdance", as connoting

the requisite "folkness" and "tradition" that render accuracy irrelevant. The culture and impact of "Riverdance" in the United States has produced and embraced an eager consumerist audience that considers Irish music authentic, historical and traditional (2002: 22).

"Riverdance" here is used as the most prominent contemporary example of popular Irish cultural products that have further cemented the historical lineage (perceived and real) that pervades the Newfoundland consciousness. The current popularity of the "Celtic" in Newfoundland along with Newfoundland's cultural revolution has resulted in a tendency towards Irishness, in that Newfoundlanders as a people have tended to naturalize an Irish identity that binds them together, regardless of individuals' personal ancestry. Similar to Reginald Byron's discussion of social propinquity in terms of Irish identity among children adopted by Irish-American parents (1999: 222), Newfoundlanders do not necessarily need to be of Irish lineage themselves in order to conform to the collective Irish identity among the Newfoundland culture as a whole.

There are numerous ways in which this Irish identity has been popularized through the arts. Much vernacular music in Newfoundland 
today is Irish-inspired, with a number of Newfoundland musicians singing traditional and contemporary Irish songs, touring through Ireland and writing original pieces about Ireland as the motherland. Further, in 2007, this identity is also evidenced in part through economic and cultural ties between Newfoundland and Ireland: the Ireland-Newfoundland Partnership, the Irish Business Partnerships, and university funding such as the Ireland-Canada University Foundation (which is tied to Newfoundland through its founder, the late Craig Dobbin) and the Coracle Fellowship, administered through Memorial University of Newfoundland, to name a few. Through these funding agencies, creative and scholarly exchanges are occurring between the two cultures on a continual basis, further cementing the Irish identity in the Newfoundland consciousness as these projects become spread widely through the media. Of course, this identity then replicates itself through the proliferation of more creative products. Newfoundland cultural products are linked to Irishness, in combination with Newfoundland's long history of identifying with the Irish. It is the fact that this common construction of identity is used as a means of indicating Newfoundland's distinct cultural place within Canada that Irish-Newfoundland dance becomes a significant means of analyzing Newfoundland identity.

As Jessica Tomell-Presto argues in her dissertation Performing Irish Identities Through Irish Dance, those of Irish descent (in her case study, Irish-Americans) will often individualize Irish dance to suit local factors within the confines of the created Irish identity (2003: 169). The pervasiveness of the Irish influence on the arts in Newfoundland and Labrador has led to some confusion as to what kinds of step dancing are, in fact, vernacular in the Newfoundland context. In her article, "Perceptions of Irish Step Dance: National, Global, Local," Catherine Foley discusses the issue of identity in Ireland as reflected in "Riverdance." She uses the case study of "Riverdance" to illustrate how forms of cultural representation tend to become homogenized; she argues, that, "Riverdance theatricalized Irish step dance from a Western perspective" (2001: 39). The homogeneous nature of "Riverdance" is one reason for its appeal; its implication of Irishness may be one reason why it has been easily integrated into Newfoundland culture and, in fact, is considered by some to actually be traditional Irish - or Newfoundland — step dancing. 
But the significance of the Irish identity as related to dance harkens back prior to the days of "Riverdance". In Catherine Foley's dissertation on step dancing in North Kerry, she identifies the construction of identity as being crucial to the linking of Irish dancing to its culture. As Frank Hall observes in his dissertation on competitive Irish step dancing, this linking of dance to culture in Ireland was intrinsically politicized, as was the nature of creating an Irish identity at the time (1997: 139142). Foley argues (and Frank Hall agrees) that it was the establishment of both the Gaelic Athletic Association and the Gaelic league, dealing with Irish sports and language respectively, that imprinted the importance of Irish cultural products on the collective consciousness of its people (Foley 1988: 81-82). She states:

The League's objective was to create a cultural Irish nation which would establish Ireland in the eyes of the world as being a separate nation with its own national identity.... dance [as] a part of the Gaelic League and functioned as a told in projecting the Irish image (82).

This led to the creation of the Irish Dancing Commission (An Coimisiún le Rincí Gaelachn) in 1929, which is the driving force behind the competitive nature of Irish dancing in the Irish diaspora worldwide (Foley 1988: 89). While the competitive system does not (yet) exist in Newfoundland, the influence from both the Commission and "Riverdance" is felt in the popularity of Irish culture through dance in the province today.

The misconception that traditional Irish step dance is, in fact, vernacular step dancing, is one that is found in both Ireland and Newfoundland. Foley argues that traditional Irish step dance has survived in marginal communities that have better survived cultural modernization than their urban counterparts (2001: 41). In Newfoundland and Labrador, vernacular step dancing has undergone recontextualization, and Irish-Newfoundland step dancing endures through the efforts of the St. Pat's Dancers. Traditional Irish (or "Riverdance") step dance is at an embryonic stage at the time of writing, finding its place amongst its two sister traditions. While it is wonderful that a complementary style can find a place in Newfoundland culture, this particular dance style has caused some controversy in recent years.

Musician and set dancer Jim Payne, and Dance Studio East owner and instructor Martin Vallee have both written letters to the editor of 
The Telegram newspaper in 2002 and 2004 respectively, challenging published articles that implied that "Riverdance" style step dance is the first kind of step dancing to exist in this province. ${ }^{10}$ Both articulated the heritage of vernacular and Irish-Newfoundland step dancing, stressing the fact that traditional Irish step is a recent phenomenon in Newfoundland, not a long-standing tradition (Payne 2002 and Vallee 2004). As much as this dance style is integrated into popular culture, it enjoys a very different status from other kinds of step dancing among those in the folk and dance communities in the province. Its connection to Irish culture, however tenuous in reality, is significant to its popularity in Newfoundland and Labrador culture today.

So the richness of step dance traditions has resulted in some confusion both within and outside the dance community in Newfoundland and Labrador; regardless, step dancing and its Irish connection is firmly embedded in the collective consciousness of this province. And, as a well-known and highly respected dance group, and the first and arguably the highest profile step dance group in the province, the St. Pat's Dancers are then the very embodiment of the Irish-Newfoundland style so entrenched in Newfoundland culture. The Steiners, and the dancers, take this role very seriously. Jeff Steiner says this about tradition and the St. Pat's Dancers in an interview for The Evening Telegram in 1997:

We haven't officially developed a mission statement for the group itself, but what we try to stress to the kids is that this is a 65 -year old tradition that a lot of people have put a lot of work into over 65 years. When they come into the troupe they're made aware of that and they do try to carry that tradition because we are trying to preserve part of the culture, too (Vaughn-Jackson).

Thus the dancers are aware of the lineage of the group, and the pride that comes from carrying on a tradition such as this. The Steiners take great pains, then, to allow not only for the flourishing of the dance form, but also for the children to form an identity as a St. Pat's Dancer, and its corresponding heritage, as well as with Irish-Newfoundland step dancing, and the cultures that it is tied to.

10. The controversy stems from two separate articles on Shawn Silver, on his dance school and on an ACOA (Atlantic Canada Opportunities Agency) grant he received to study step dancing in Ireland. The two letters to the editor refuted statements that Silver made about traditional Irish step dance being the first kind of step dancing in the province. (See Payne 2002 and Vallee 2004). 
In her introduction to Cultural Memory and the Construction of Identity, Liliane Weissberg discusses the link between culture and the collective social group. She argues that cultural memory is linked not only to the past, but also frames the present (Ben-Amos and Weissberg 1999: 16-18). It is the perceived cultural link to Ireland that informs Newfoundland's identity to a large extent, even if the Irish were not the only, or even the most predominant settlers to the province. To draw a parallel to the St. Pat's Dancers, the cultural background of the child is not relevant here; it is the cultural memory of Newfoundland as Irish, and the dance style's Irish roots, that are of import. And that is what enables the dance form to not only continue, but to remain a prevalent force in the folk arts community in Newfoundland and Labrador, and allow the St. Pat's Dancers their prominence in Newfoundland culture today.

Over their sixty-plus year existence, the St. Pat's Dancers has become prominent in both artistic communities and in the consciousness of the general public in the province. Starting as part of the education system in one school, the group has spread in numbers and has therefore acclimatized itself in its Newfoundland home. By allowing the children to teach each other, to choreograph new pieces and set them to local tunes (Steiner 2004 and 2005), the St. Pat's Dancers truly embraced the hybrid nature of Irish-Newfoundland step dance. The heritage of the group is perhaps expressed best by Jeff and Yvonne Steiner:

[We] remain committed because it allows the students to take pride in an organization that has been around for more than 60 years. Not only are the students fashioning a stronger character for themselves, but they are making Newfoundlanders proud while dancing into the hearts of fans everywhere (Green 1996: 11).

As a group for children, the St. Pat's Dancers is significant in that it provides many of the physical and emotional benefits of dancing: physical fitness, coordination, rhythm, and a sense of accomplishment at mastering new skills. Further, as children become senior members of the group, there are some very significant rewards, namely, that they become part of the performance group, and they are permitted to become instructors to the new recruits. Perhaps one of the most significant gifts - at least for some - from the experience of being a St. Pat's Dancer is the cultural link to Newfoundland past and present. While it may not overtly be a part of every rehearsal, the heritage of the group and its roots with Irish dance are gently incorporated into 
the activities of the group, from their considerable involvement in St. Patrick's Day celebrations to the Newfoundland tartan that the children wear in a show. Thus a feeling of pride is instilled in the children, enabling in both the dancer and the public they entertain, the collective memory of Newfoundland's Irish heritage to continue. 


\section{References}

Baird, Monica. 2006. "Newfoundland not as Irish as Some Think." The Telegram, 14 October : 1-4.

Ben-Amos, Dan and Liliane Weissberg, eds. 1999. Cultural Memory and the Construction of Identity. Detroit: Wayne State University Press.

Byrne, Pat. 1991. “'Stage Irish' in Britain's Oldest Colony: Introductory

Remarks Towards an Analysis of the Influence of the McNulty Family on Newfoundland Music." Canadian Folklore Canadien 13(1): 59-68.

Byron, Reginald. 1999. Irish America. Oxford: Oxford University Press. Casey, Natasha. 2002. "Riverdance: The Importance of Being Irish American." New Hibernia Review/Iris Éireannach Nua 6 (4): 9-25.

Foley, Catherine. 1988. Irish Traditional Step Dancing in North Kerry: A Contextual and Structural Analysis. Unpublished dissertation: Laban

Centre for Movement and Dance, University of London Goldsmiths' College.

__ 2001. "Perceptions of Irish Step Dance: National, Global, Local." Dance Research Journal 33: 34-45.

Gedutis, Susan. 2004. See You at the Hall: Boston's Golden Era of Irish Music and Dance. Boston: Northeastern University Press.

Green, Jeff. 1996. "Dancing into the Hearts of Nova Scotians: The St. Pat's Dancers." The Monitor, September: 10-11.

Hall, Frank A .1997. Irish Dancing: Discipline as Art, Sport and Duty. Unpublished dissertation: Indiana University.

Harvey, David C. et al, eds. 2002. Celtic Geographies: Old Culture, New Times. London and New York: Routledge.

Innes, Fran. 1979. "'Hoofer' Andrew Base: From Hopedale to the St. Pat's Dancers." Newfoundland TV Topics, 22 May : 4-6.

Johnston, Thomas F. 1996. "Irish Folk Dance in Social Perspective." Acta Ethnographica Hungaria: An International Journal of Ethnography 41(1-4): 277-91.

Long, Lucy and Tony Howard, producers. 1999. To Dance Irish. Bowling Green: WBGU-TV.

Mannion, John. 2007. Personal Interview. 24 August.

McDonald, Terry. 1999. "Where Have All The (English) Folk Songs Gone? Newfoundland's Rejection of its Dorset Inheritance." British Journal of Canadian Studies 14 (2): 180-192.

McKay, Ian. 1992. "Tartanism Triumphant: The Construction of Scottishness in Nova Scotia, 1933-1954." Acadiensis 21 (2): 5-47. 
Narváez, Peter and Martin Laba, eds. 1986. Media Sense: The FolklorePopular Culture Continuum. Bowling Green: Bowling Green State University Popular Press.

Overton, James. 1996. Making a World of Difference: Essays on Tourism, Culture and Development in Newfoundland. St. John's: ISER.

Payne, Jim. 2002. "Not From Here: Explanation for Dance Project Out of Step with Province's Actual Dance History." The Telegram, 3 August 2002.

Posen, I. Sheldon. 1993. "On Folk Festivals and Kitchens: Questions of Authenticity in theFolksong Revival." In Rosenberg, Neil V., eds., Transforming Tradition:Folk Music Revivals Examined. Urbana, IL: University of Illinois Press.

"St. Pat's Dancers." Newfoundland and Labrador Heritage http:// www.heritage.nf.ca/arts.st_pats.html, retrieved 6 September 2002.

St. Pat's Dancers. 1992.

St. Pat's Dancers General Information. No date.

Steiner, Yvonne. 2004. Personal Interview. 15 March. and Jeff Steiner. 2005. Personal Interview. 30 September.

The St. Pat's Dancers. Summary Information. No date.

"The St. Pat's Dancers: 60 Years of Irish Culture 1994." The Monitor April: 18-19.

Toelken, Barre. 2003. "The Heritage Arts Imperative". Lournal of American Folklore 116: 196-205.

Tomell-Presto, Jessica. 2003. Performing Irish Identities Through Irish Dance. Unpublished dissertation, Southern Illinois University Carbondale.

Vallee, Martin. 2004. "Nothing New About Irish Dancing" The Telegram, 15 October.

Vaughn-Jackson, Mark. 1997. "Stepping Out: The St. Pat's Dancers are Headed for Parliament Hill." The Evening Telegram, 20 June 1. 